\title{
ANALYSIS OF THREE-YEAR PREVALENCE OF ORAL CAVITY, NECK AND HEAD TUMORS - A RETROSPECTIVE SINGLE-CENTRE STUDY
}

\author{
Sinan Rusinovci ${ }^{1}$, Xhevdet Aliu $^{1}$, Tomislav Jukić ${ }^{2}$, David Stubljar $^{3}$ and Naim Haliti ${ }^{1}$ \\ ${ }^{1}$ Prishtina Faculty of Medicine, Prishtina, Kosovo; \\ ${ }^{2}$ Osijek Faculty of Medicine, Josip Juraj Strossmayer University of Osijek, Osijek, Croatia; \\ ${ }^{3}$ In-Medico, Department of Research and Development, Metlika, Slovenia
}

\begin{abstract}
SUMMARY - The purpose of the study was to retrospectively analyze the prevalence of oral cavity, neck and head tumors recorded at our department over a period of 3 years. Retrospective analysis included archival data on cancer patients treated at our department during the 2015-2017 period. A total of 1005 patients with proven carcinomas were selected for final analysis. Cancers were detected by ultrasound, $\mathrm{x}$-ray, biopsy and clinical diagnosis. The mean age of patients was $58.4 \pm 19.3$ years. The majority of cases $(n=264 ; 26.3 \%)$ were detected in the $7^{\text {th }}$ decade of life. The most common cancers were basal cell carcinoma in $374(37.2 \%)$ and squamous cell carcinoma in 228 (22.7\%) cases. The male-to-female ratio was $1.7: 1$. There was no statistically significant age difference between genders. Recurrence of tumor occurred in 31 patients. The most common risk factor in both groups was sun exposure. The most common sites were lower lip, cheek and frontal region in men, and cheek region and nose in women $(\mathrm{p}<0.001)$. Men were found to be more susceptible to cancer development. This study showed differences between age groups, i.e. elderly patients had a much higher probability of developing cancer as compared to younger patients.
\end{abstract}

Key words: Three-year data; Prevalence; Oral cancers; Risk factors; Retrospective analysis

\section{Introduction}

Oral cancers are malignant neoplasms that develop in the tissues of the mouth ${ }^{1}$. Oral cancers are the $6^{\text {th }}$ most common malignancy worldwide. Despite the general global trend of a slight decrease in the incidence of oral cancers, the incidence of tongue cancer is increasing ${ }^{2}$. About $90 \%$ of all tumors are histologically subtyped as oral squamous cell carcinoma (OSCC), which is the most common type of oral cancer. Each year, about 275,000 cases are newly diagnosed worldwide, reporting 128,000 deaths annually ${ }^{3}$. In the Euro-

Correspondence to: Assist. Prof. Naim Haliti, PhD, Faculty of Medicine, Department of Forensic Medicine, Rrethi i Spitalit, 10000 Prishtina, Republic of Kosovo

E-mail: naim.haliti46@gmail.com

Received May 23, 2018, accepted October 22, 2018 pean Union, there is an estimate of 66,650 new cases each year ${ }^{4}$. At an early stage, OSCC has a survival rate of $80 \%$ in comparison to late stages (T3-T4) when the survival rate is only $20 \%-30 \% 5$. The incidence varies by geographic regions, and more than half of all cases occur in developing countries ${ }^{6}$; however, in the last decade, an increase has been observed in the percentage of young patients ${ }^{2}$.

Early diagnosis of oral cancer is the most important factor affecting overall survival and prognosis. Several countries in Europe have shown a significant increase in the prevalence of oral cancer, especially in men. Oral cancer is more common in men and usually occurs after the $5^{\text {th }}$ decade of life ${ }^{4}$. For instance, in $\mathrm{Eu}-$ rope, head and neck cancers are the $4^{\text {th }}$ most common group of cancers among men ${ }^{7}$. France has one of the highest incidence rates; in 2012, the world-standard- 
ized incidence for men was 21.5 cases per 100,000 person-years and in France over 35 cases per 100,000 person-years for men ${ }^{8,9}$.

Apart from tobacco and alcohol, dietary factors, human papillomavirus (HPV) infection, genetic factors, and oral hygiene have also been reported as risk factors. Social inequalities were related to oral cavity cancers, linked to factors directly affecting behavior and lifestyle of different genders ${ }^{3,10}$. Studies have reported an alarming lack of awareness about oral cancer, symptoms and early diagnosis. The lack of such knowledge needs to be addressed by further public education, and possibly targeted at high-risk groups ${ }^{11}$. Tobacco and alcohol consumption are still the principal etiologic factors for the development of squamous cell carcinoma (SCC). However, in addition, a variety of suspected risk factors such as chronic irritation, poor oral hygiene, viral infection, occupational exposure, nutrition, and genetic factors have been proposed for the development of oral cancer ${ }^{12-16}$.

The aims of this study were to retrospectively analyze the prevalence of oral cavity, neck and head carcinoma and evaluate the number of different types of cancers encountered at our department over a 3-year period (2015-2017).

\section{Materials and Methods}

The study was designed as retrospective analysis of data from the Department of Maxillofacial Surgery, University Clinical Center of Kosovo, Prishtina, Kosovo. The research was conducted in full accordance with the Declaration of Helsinki on medical protocols and ethics. The study was approved by the Prishtina Faculty of Medicine Review Board. Patient consent for participation was not required since data were retrieved from our archive database, protecting privacy and confidentiality of patient data.

The archive contained number of cancer patients treated at our department from 2015 to 2017. A total of 1005 patients with proven carcinomas of the oral cavity, neck and head were selected for final analysis. Cancers were detected by ultrasound, $\mathrm{x}$-ray, biopsy and clinical diagnosis. Cases were divided into groups according to histopathologic diagnosis of cancer type. Statistical analysis was performed by Statistical Package of Social Sciences SPSS 21 (IBM, New York, USA). Student's t-test and Pearson's $\chi^{2}$-test were per- formed according to the type of variable. Cox regression was calculated for the evaluation of hazard ratio (HR) between independent and dependent variables. Statistical significance for all tests was set at $\mathrm{p}<0.05$.

\section{Results}

Of the 1005 cases, 936 (93.1\%) cases were diagnosed by clinical evaluation, $182(18.1 \%)$ were confirmed by biopsy, 132 (13.1\%) were confirmed by imaging (computed tomography, orthopan, craniogram), and $56(5.6 \%)$ with ultrasound. The mean age of the study patients was $58.4 \pm 19.3$ years. The majority of cases $(n=264 ; 26.3 \%)$ were detected in the $7^{\text {th }}$ decade of life (60-69 age group). Altogether 580 (57.7\%) cases were elderly people aged $\geq 60$ (Fig. 1 ). Furthermore, 19 $(1.9 \%)$ cases were detected in children aged $\leq 9$ years.

In cancer patients, the most common type of occupation was retirement $(\mathrm{n}=467 ; 46.5 \%)$ and field worker ( $\mathrm{n}=207 ; 20.6 \%$ ) (Table 1). We did not establish the types of field work, since it could contribute to cancer as one of the risk factors. Sun exposure was determined as the most frequent risk factor in more than half of cases. Treated patients had undergone surgery for their primary tumor. Only a minority of them received chemotherapy or radiotherapy (alone or combined). The mean time elapsed from diagnosis to treatment (time-to-treat) was more than 22 months.

The most common oral cancer was basal cell carcinoma (BCC), found in 374 (37.2\%) cases, followed by $\mathrm{SCC}$ in $228(22.7 \%)$ cases as the second most prevalent cancer. Other types of cancers are listed in Table 2.

The male-to-female ratio of cancer patients was 1.7:1. According to age groups, there was no statistical difference between male and female patients, since most patients of both genders belonged to elderly groups. Recurrence of tumor occurred in 31 patients, but with no statistical gender difference. However, 50 men had multiple-site tumors compared to 15 cases in women $(\mathrm{p}=0.019)$. The most common risk factor in both groups was sun exposure and contribution of multiple factors, mostly a combination of sun exposure, alcohol and tobacco use (Table 3).

Distribution of cancers by anatomic regions was different depending on patient gender $(\mathrm{p}<0.001)(\mathrm{Ta}-$ ble 4). The most common sites were lower lip, cheek region and frontal region in men, and cheek region and nose in women. 


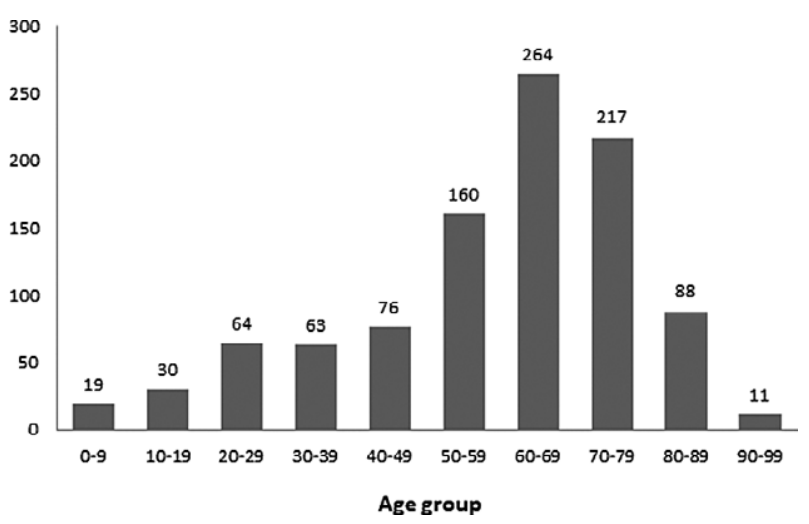

Fig. 1. Age distribution of patients with oral and maxillofacial tumors.

In the cheek region, skin carcinoma and carcinomas at buccal site of the mouth and mucosa were identified. As this region was identified most commonly, we calculated HR for independent variables (patient risk factors) to predict the occurrence of cancer in the cheek anatomic region (Table 5). Statistically significant risk factors for cancers in the cheek region were male gender, age 60-69 years, retired and field workers, cancer in only one region, and patients with known risk factors such as sun exposure, tobacco use, or their combination.

\section{Discussion}

The purpose of the current study was to retrospectively analyze the prevalence of oral cavity, neck and head carcinomas, and estimate the prevalence of cancer subtypes at our department over a period of 3 years. The mean age of cancer patients in our study was 58.4 years, which coincided with the findings from UAE $(54.9 \text { years })^{17}$, Thailand (59.1 years) ${ }^{18}$, Iran (61.2 years $)^{19}$, Malaysia $(61.2 \text { years })^{20}$, Jordan $(62.5 \text { years })^{21}$ and Japan $(65.2 \text { years })^{22}$ but higher than data reported from Nigeria (42.2 years) ${ }^{23}$ and India (47.8 and 49.7 years $)^{24,25}$. However, the majority of patients $(n=580$ cases; $57.7 \%$ ) were elderly people aged $>60$. As previously confirmed in many other studies ${ }^{19,21,26,27}$, male patients predominated with the male to female ratio of 1.7:1 (for example, HR for cheek cancer in male patients was 1.497; $\mathrm{p}=0.003$ ).

Disparity in the prevalence of different cancer subtypes might be attributable to difference in the distribution of risk factors in each patient or geographical
Table 1. Basic characteristics of patients with oral and maxillofacial tumors

\begin{tabular}{|c|c|}
\hline & $\begin{array}{l}\text { Patients with oral and } \\
\text { maxillofacial tumors }(\mathrm{N}=1005)\end{array}$ \\
\hline Age (years) & $58.4 \pm 19.3$ \\
\hline Gender: & \\
\hline Male/Female & $636 / 369$ \\
\hline $\begin{array}{l}\text { Year of cancer } \\
\text { diagnosis: }\end{array}$ & \\
\hline 2015 & 311 \\
\hline 2016 & 376 \\
\hline 2017 & 318 \\
\hline Profession: & \\
\hline Worker & 122 \\
\hline Housewife & 122 \\
\hline Retiree & 467 \\
\hline Pupil & 27 \\
\hline Student & 43 \\
\hline Child $<6$ years & 17 \\
\hline Field worker & 207 \\
\hline Birthplace: & \\
\hline Village & 679 \\
\hline City & 326 \\
\hline Risk factors: & \\
\hline Sun exposure & 518 \\
\hline Tobacco & 57 \\
\hline Alcohol & 12 \\
\hline Viral infection & 4 \\
\hline $\begin{array}{l}\text { Chemical } \\
\text { materials }\end{array}$ & 4 \\
\hline No data & 201 \\
\hline Multiple factors & 209 \\
\hline Family history & 59 \\
\hline $\begin{array}{l}\text { Time-to-treat } \\
\text { (months), mean }\end{array}$ & $22.3 \pm 27.8$ \\
\hline $\begin{array}{l}\text { Time-to-treat } \\
\text { (months), median }\end{array}$ & $8.5 \pm 0.9$ \\
\hline Treatment: & \\
\hline Surgery & 985 \\
\hline Chemotherapy & 1 \\
\hline Radiotherapy & 1 \\
\hline Medications & 17 \\
\hline
\end{tabular}

features of the region where the patient lived ${ }^{17,23}$. In our study, alcohol and smoking were not the dominant 
Table 2. Prevalence and types of cancer diagnosed during 3-year period (2015-2017)

\begin{tabular}{|c|c|}
\hline Histology of cancer & $\begin{array}{l}\text { Total number of } \\
\text { cancers }(\mathrm{N}=1005)\end{array}$ \\
\hline Adenocystic carcinoma & $1(0.1 \%)$ \\
\hline Pleomorphic adenoma & $7(0.7 \%)$ \\
\hline Adenoma sebaceum & $2(0.2 \%)$ \\
\hline Ameloblastoma & $3(0.3 \%)$ \\
\hline Angiofibroma & $5(0.5 \%)$ \\
\hline Hemangioma, calcifying & $1(0.1 \%)$ \\
\hline Basal cell epithelioma & $1(0.1 \%)$ \\
\hline $\begin{array}{l}\text { Lymph node metastatic } \\
\text { carcinoma }\end{array}$ & $5(0.5 \%)$ \\
\hline Mucoepidermoid carcinoma & $2(0.2 \%)$ \\
\hline Sebaceous carcinoma & $1(0.1 \%)$ \\
\hline Verrucous carcinoma & $6(0.6 \%)$ \\
\hline Basal cell carcinoma & $284(28.3 \%)$ \\
\hline Adenoid basal cell carcinoma & $53(5.3 \%)$ \\
\hline Basal cell carcinoma, cornifying & $2(0.2 \%)$ \\
\hline Basal cell carcinoma cutis & $3(0.3 \%)$ \\
\hline $\begin{array}{l}\text { Basal cell carcinoma with } \\
\text { squamous metaplasia }\end{array}$ & $1(0.1 \%)$ \\
\hline Basal cell carcinoma, pigmented & $2(0.2 \%)$ \\
\hline $\begin{array}{l}\text { Basal cell carcinoma, adenoid } \\
\text { cystic }\end{array}$ & $3(0.3 \%)$ \\
\hline $\begin{array}{l}\text { Basal cell carcinoma, adenoid } \\
\text { keratinizing }\end{array}$ & $1(0.1 \%)$ \\
\hline Basal cell carcinoma, fibrotic & $3(0.3 \%)$ \\
\hline $\begin{array}{l}\text { Basal cell carcinoma, } \\
\text { hyperkeratotic }\end{array}$ & $1(0.1 \%)$ \\
\hline $\begin{array}{l}\text { Basal cell carcinoma, } \\
\text { keratinizing }\end{array}$ & $2(0.2 \%)$ \\
\hline Basal cell carcinoma, keratotic & $2(0.2 \%)$ \\
\hline Basal cell carcinoma, superficial & $17(1.7 \%)$ \\
\hline Chalazion & $1(0.1 \%)$ \\
\hline Epidermal inclusion cyst & $1(0.1 \%)$ \\
\hline Clear cell hidradenoma & $2(0.2 \%)$ \\
\hline Squamous cell carcinoma & $204(20.3 \%)$ \\
\hline $\begin{array}{l}\text { Squamous cell carcinoma, } \\
\text { corneal }\end{array}$ & $7(0.7 \%)$ \\
\hline $\begin{array}{l}\text { Squamous cell carcinoma, } \\
\text { cornifying }\end{array}$ & $15(1.5 \%)$ \\
\hline $\begin{array}{l}\text { Lymph node metastatic } \\
\text { squamous cell carcinoma }\end{array}$ & $1(0.1 \%)$ \\
\hline
\end{tabular}

\begin{tabular}{|c|c|}
\hline Histology of cancer & $\begin{array}{l}\text { Total number of } \\
\text { cancers }(\mathrm{N}=1005)\end{array}$ \\
\hline $\begin{array}{l}\text { Squamous cell carcinoma, non } \\
\text { corneal }\end{array}$ & $1(0.1 \%)$ \\
\hline Cylindroma & $2(0.2 \%)$ \\
\hline Dermatofibroma & $1(0.1 \%)$ \\
\hline Dermatofibrosarcoma & $2(0.2 \%)$ \\
\hline Fibrous dysplasia & $5(0.5 \%)$ \\
\hline Epulis & $3(0.3 \%)$ \\
\hline Fibromatous epulis & $3(0.3 \%)$ \\
\hline Giant cell epulis & $9(0.9 \%)$ \\
\hline Fibroepithelial polyp & $2(0.2 \%)$ \\
\hline Fibrohistiocytoma & $1(0.1 \%)$ \\
\hline Fibrolipoma & $17(1.7 \%)$ \\
\hline Fibropapilloma & $2(0.2 \%)$ \\
\hline Fibromyxoma & $1(0.1 \%)$ \\
\hline Pyogenic granuloma & $20(2.0 \%)$ \\
\hline Hemangioma & $5(0.5 \%)$ \\
\hline Capillary hemangioma & $9(0.9 \%)$ \\
\hline Cavernous hemangioma & $4(0.4 \%)$ \\
\hline Verrucous hemangioma, partial & $1(0.1 \%)$ \\
\hline Sclerosing hemangioma & $4(0.4 \%)$ \\
\hline Hemangioma simplex & $7(0.7 \%)$ \\
\hline Hemangioma simplex, capillary & $1(0.1 \%)$ \\
\hline $\begin{array}{l}\text { Hemangioma simplex, } \\
\text { cutaneous }\end{array}$ & $2(0.2 \%)$ \\
\hline $\begin{array}{l}\text { Fibromatous histiocytoma, } \\
\text { benign }\end{array}$ & $1(0.1 \%)$ \\
\hline Hyperkeratosis & $16(1.6 \%)$ \\
\hline $\begin{array}{l}\text { Pseudoepitheliomatous } \\
\text { hyperplasia }\end{array}$ & $1(0.1 \%)$ \\
\hline Keratoacanthoma & $25(2.5 \%)$ \\
\hline Keratosis & $1(0.1 \%)$ \\
\hline Actinic keratosis & $9(0.9 \%)$ \\
\hline Seborrheic keratosis & $33(3.3 \%)$ \\
\hline Solar keratosis & $10(1.0 \%)$ \\
\hline Leukoplakia & $21(2.1 \%)$ \\
\hline Lichen planus & $3(0.3 \%)$ \\
\hline Lichen simplex, chronic & $1(0.1 \%)$ \\
\hline Lichenoid solar keratosis & $1(0.1 \%)$ \\
\hline Hodgkin lymphoma & $1(0.1 \%)$ \\
\hline
\end{tabular}


Table 2. Continued

\begin{tabular}{|c|c|}
\hline Histology of cancer & $\begin{array}{l}\text { Total number of } \\
\text { cancers }(\mathrm{N}=1005)\end{array}$ \\
\hline Lipoma & $15(1.5 \%)$ \\
\hline $\begin{array}{l}\text { Malignant melanoma, } \\
\text { metastatic }\end{array}$ & $4(0.4 \%)$ \\
\hline Malignant melanoma, nodular & $3(0.3 \%)$ \\
\hline Mucoepidermoid carcinoma & $1(0.1 \%)$ \\
\hline Myoblastoma & $1(0.1 \%)$ \\
\hline Dermal nevus & $1(0.1 \%)$ \\
\hline Epidermodermal nevus & $5(0.5 \%)$ \\
\hline Nevocellular nevus & $6(0.6 \%)$ \\
\hline Pigmented nevus & $14(1.4 \%)$ \\
\hline $\begin{array}{l}\text { Pigmented nevus, } \\
\text { epidermodermal }\end{array}$ & $15(1.5 \%)$ \\
\hline Pigmented nevus, intradermal & $18(1.8 \%)$ \\
\hline Sebaceous nevus & $3(0.3 \%)$ \\
\hline Verrucous nevus, intradermal & $1(0.1 \%)$ \\
\hline Antoni A neurilemmoma & $1(0.1 \%)$ \\
\hline Neurofibroma & $4(0.4 \%)$ \\
\hline Nevocellular nevus, intradermal & $1(0.1 \%)$ \\
\hline Non-Hodgkin lymphoma & $1(0.1 \%)$ \\
\hline Osteoma & $3(0.3 \%)$ \\
\hline Papilloma & $17(1.7 \%)$ \\
\hline Papilloma, inflammatory & $1(0.1 \%)$ \\
\hline Papilloma, verrucous & $6(0.6 \%)$ \\
\hline Polyposis & $1(0.1 \%)$ \\
\hline Rhabdomyoma & $1(0.1 \%)$ \\
\hline Sebaceous trichofolliculoma & $1(0.1 \%)$ \\
\hline Sebaceoma & $1(0.1 \%)$ \\
\hline Spindle cell nevus & $1(0.1 \%)$ \\
\hline Syringoma & $1(0.1 \%)$ \\
\hline Benign cystic teratoma & $1(0.1 \%)$ \\
\hline Trichoepithelioma & $3(0.3 \%)$ \\
\hline Trichofolliculoma & $1(0.1 \%)$ \\
\hline Giant cell tumor & $1(0.1 \%)$ \\
\hline $\begin{array}{l}\text { Ulcerative eosinophilic } \\
\text { granuloma (Riga-Fede disease) }\end{array}$ & $1(0.1 \%)$ \\
\hline Verruca vulgaris & $1(0.1 \%)$ \\
\hline $\begin{array}{l}\text { Warthin tumor (papillary } \\
\text { lymphomatous cystadenoma) }\end{array}$ & $1(0.1 \%)$ \\
\hline No data & $5(0.5 \%)$ \\
\hline
\end{tabular}

Table 3. Characteristics of cancer patients according to gender

\begin{tabular}{|l|l|l|l|}
\hline & $\begin{array}{l}\text { Male } \\
(\mathrm{N}=636)\end{array}$ & $\begin{array}{l}\text { Female } \\
(\mathrm{N}=369)\end{array}$ & p-value \\
\hline Age group (years): & 12 & 7 & 0.582 \\
$0-9$ & 15 & 15 & \\
$10-19$ & 38 & 26 & \\
$20-29$ & 42 & 21 & \\
$30-39$ & 52 & 24 & \\
$40-49$ & 108 & 52 & \\
$50-59$ & 163 & 99 & \\
$60-69$ & 133 & 84 & \\
$70-79$ & 58 & 29 & \\
$80-89$ & 5 & 6 & \\
$90-99$ & 10 & 6 & \\
No data & 18 & 13 & 0.620 \\
\hline Recurrence & & & $<0.001$ \\
\hline Risk factors: & 327 & 188 & \\
Sun exposure & 40 & 15 & \\
Tobacco & 9 & 2 & \\
Alcohol & 3 & 1 & \\
Viral infection & 1 & 3 & \\
Chemical materials & 158 & 47 & \\
Multiple factors & 98 & 113 & \\
No data & 34 & 23 & 0.550 \\
\hline Family history & 50 & 15 & 0.019 \\
\hline Multi-site & & & \\
\hline
\end{tabular}

risk factors. Sun exposure was detected as a risk factor for cancer development in more than $50 \%$ of all cases. Kosovo as a geographic region has the Mediterranean climate with lots of sunny days annually. In addition, general perception of sunbathing is that sunlight is not harmful, therefore people do not avoid the mid-day summer sun. For this reason, it would be of great interest to evaluate the prevalence of skin cancer in the population. Most of the oral, neck and head cancers in the present study were located in the cheek region of the head/face, lower lip, nose and frontal region. The reasons apart from risk factors were not determined. We demonstrated that gender, age, sun exposure and tobacco use could statistically contribute to cancer in this region. Previous studies mostly diagnosed cancer on the tongue ${ }^{17,19,22,28-30}$. The reasons why the tongue and cheek were the predilection sites for oral cancer in 
Table 4. Distribution of cancers according to anatomic region and patient gender

\begin{tabular}{|l|l|l|l|l|}
\hline Anatomic region & $\begin{array}{l}\text { Number of patients } \\
(\mathrm{N}=1005)\end{array}$ & Percent of patients & $\begin{array}{l}\text { Male } \\
(\mathrm{N}=636)\end{array}$ & $\begin{array}{l}\text { Female } \\
(\mathrm{N}=369)\end{array}$ \\
\hline Lower lip & 167 & $16.6 \%$ & 139 & 28 \\
Upper lip & 28 & $2.9 \%$ & 11 & 17 \\
Nose & 143 & $14.2 \%$ & 78 & 65 \\
Frontal region & 114 & $11.3 \%$ & 85 & 29 \\
Cheek region & 221 & $22.0 \%$ & 115 & 106 \\
Region covered with hair & 92 & $9.2 \%$ & 66 & 26 \\
Parotid gland & 6 & $0.6 \%$ & 1 & 5 \\
Palate & 5 & $0.5 \%$ & 4 & 1 \\
Medial canthus of eye & 10 & $1.0 \%$ & 6 & 4 \\
Lateral canthus of eye & 8 & $0.8 \%$ & 4 & 4 \\
Upper eyelid & 9 & $0.9 \%$ & 5 & 4 \\
Lower eyelid & 9 & $0.9 \%$ & 6 & 3 \\
Neck region & 40 & $4.0 \%$ & 23 & 16 \\
Oral mucosa & 10 & $1.0 \%$ & 4 & 6 \\
Tongue & 17 & $1.7 \%$ & 10 & 7 \\
Gingiva & 16 & $1.6 \%$ & 3 & 13 \\
Floor of the mouth & 0 & 0 & 0 & 0 \\
Ear & 27 & $2.7 \%$ & 22 & 5 \\
Other salivary glands & 1 & $0.1 \%$ & 0 & 1 \\
Upper jaw & 18 & $1.8 \%$ & 13 & 5 \\
Lower jaw & 9 & $0.9 \%$ & 7 & 2 \\
Frontal bone & 1 & $0.1 \%$ & $8.3 \%$ & \\
No data & 54 & & \\
\hline
\end{tabular}

those studies are that the carcinogens mixing with saliva in the oral cavity have a tendency to pool at the bottom of the mouth and these sites are covered by thin and non-keratinized mucosa, thus providing less protection against the carcinogen ${ }^{31}$. On the other hand, Chidzonga ${ }^{32}$ reports on gingiva as the most common site of oral cancer, followed by the tongue. In our study, tongue and gingiva cancer together accounted for only $3.3 \%$ of all cancers. However, Howell et $a l .^{33}$ report that the most common site of oral cancer in their study was the lip, followed by the tongue, which coincided with our findings regarding lip cancer. The explanation for the high incidence of lip cancer was sun exposure and ultraviolet light overexposure, which also coincided with our results. Australia, where the study was performed, also is a sunny country and its residents, mostly immigrants from Europe, have fair skin complexion and thus higher probability of skin damage. A study from India determined cancer of buccal mucosa as the second most common in their population, attributed to tobacco chewing ${ }^{25}$. As a consequence, alveolar mucosa, gingiva and buccal mucosa are constantly in contact with the carcinogens for a long period of time. In our analysis, tobacco was identified as a risk factor in 55 patients.

Regarding cancer subtypes in the present study, BCC accounted for $37.2 \%$ and SCC for $22.7 \%$ of all oral cancers. These figures are much lower than those reported in several previous studies, which found SCC to account for $84.4 \%$ to $90.0 \%$ of all oral cancers ${ }^{2,19-20,29,33}$. However, lower figures from $63.0 \%$ to $73.1 \%$ have also been reported ${ }^{17,23,30,32}$, but not under $20 \%$ to $25 \%$. Head and neck SCC has been established worldwide as one of the most frequent cancers. Its incidence is $2.5 \%$ and it annually contributes to $1.9 \%$ of all deaths from cancer. The majority of oral cancers are 
Table 5. Predictive values of risk factors with calculated HR with 95\% CI for cancer in cheek region

\begin{tabular}{|l|l|l|l|l|l|}
\hline & B & HR & $95 \%$ CI & & p-value \\
\hline Gender & 0.404 & 1.497 & 1.146 & 1.965 & 0.003 \\
\hline Age group (years): & & & & & \\
$0-9$ & & Reference & & & \\
$10-19$ & -1.078 & 0.340 & 0,062 & 1.858 & 0.213 \\
$20-29$ & -0.932 & 0.394 & 0,098 & 1.577 & 0.188 \\
$30-39$ & -0.443 & 0.642 & 0,213 & 1.940 & 0.433 \\
$40-49$ & -0.442 & 0.643 & 0,209 & 1.976 & 0.440 \\
$50-59$ & -0.013 & 0.987 & 0,342 & 2.846 & 0.980 \\
60-69 & -1.232 & 0.292 & 0,099 & 0.859 & $\mathbf{0 . 0 2 5}$ \\
$70-79$ & -0.425 & 0.654 & 0,237 & 1.804 & 0.412 \\
$80-89$ & -0.425 & 0.654 & 0,236 & 1.811 & 0.414 \\
$90-99$ & -0.210 & 0.810 & 0,28 & 2.343 & 0.698 \\
\hline Occupation: & & & & & \\
Worker & & Reference & & & \\
Housewife & 0.543 & 1.722 & 0,951 & 3.115 & 0.073 \\
Retiree & 0.798 & 2.220 & 1,283 & 3.844 & $\mathbf{0 . 0 0 4}$ \\
Pupil & 0.575 & 1.778 & 1,116 & 2.832 & $\mathbf{0 . 0 1 5}$ \\
Student & 0.324 & 1.383 & 0,473 & 4.042 & 0.553 \\
Child <6 years & 0.997 & 2.710 & 1,240 & 5.923 & $\mathbf{0 . 0 1 2}$ \\
Field worker & 1.083 & 2.953 & 1,187 & 7.344 & $\mathbf{0 . 0 2 0}$ \\
\hline Birthplace & -0.162 & 0.850 & 0.642 & 1.127 & 0.259 \\
\hline Recurrence & -0.540 & 0.583 & 0.211 & 1.609 & 0.297 \\
\hline Multi-site & -0.912 & 0.402 & 0.198 & 0.814 & $\mathbf{0 . 0 1 1}$ \\
\hline Risk factors: & & & & & \\
Sun exposure & & Reference & & & \\
Tobacco & 0.539 & 1.714 & 1,118 & 2.627 & $\mathbf{0 . 0 1 3}$ \\
Alcohol & 0.141 & 1.151 & 0,472 & 2.810 & 0.757 \\
Various chemical & & & & & \\
materials & 1.051 & 2.861 & 0,387 & 21.169 & 0.303 \\
Multiple & 0.808 & 2.243 & 1,379 & 3.648 & $\mathbf{0 . 0 0 1}$ \\
\hline Family history & -0.132 & 0.876 & 0.524 & 1.464 & 0.614 \\
\hline
\end{tabular}

*Hazard ratios (HR) were calculated with Cox regression, where presence of cancer was dependent variable; $\mathrm{B}$ value was determined as correlation coefficient between independent and dependent variable; $95 \% \mathrm{CI}=95 \%$ confidence interval.

histologically $\mathrm{SCC}^{34}$. Head and neck SCC is normally detected in elderly people, but an increasing incidence among younger patients aged $<45$ has been observed in recent years. However, cancer in younger people is known to be a different clinical entity with different etiologic factors and pathogenesis. There is also a distinctive discrepancy in the estimated proportion of oral cancers in younger patients among different regions, e.g., North America (5.5\%), Africa (17.2\%) and Middle East (14.5\%). Therefore, we need to conduct more population-based incidence studies also in nonWestern regions to obtain a more accurate proportion of incidence in younger population, and also to identify the etiologic risk factors for the disease ${ }^{35}$. Interest- 
ingly, in previous studies on the epithelial tumor category, $\mathrm{SCC}$ was the most common tumor and the most common oral cancer ${ }^{17,19-27,29,32,33}$, while mucoepidermoid carcinoma was most prevalent in the salivary gland tumor category ${ }^{17,20,27}$, whereas in our study it accounted for only $0.1 \%$ of all cancers. The prevalence data do differ among countries, however, mostly between the Western countries and third-world countries.

Basal cell carcinoma was proved to be the most frequent subtype in our study, and is also the most common malignancy in Caucasians ${ }^{36-40}$, with over two million cases diagnosed in the USA each year ${ }^{39}$. It is believed that $\mathrm{BCC}$ originates from the basal layer of the epidermis, the interfollicular epidermis and the hair follicle ${ }^{41}$. Approximately $95 \%$ of individuals are diagnosed with BCC between the age of 40 and 79 years. The incidence is approximately $30 \%$ higher in men than in women. The risk factors include fair skin pigmentation, sun radiation (ultraviolet and/or ionizing), exposure to arsenic or polycyclic aromatic hydrocarbons, immunosuppression, scars, and certain genetic syndromes ${ }^{41}$. BCC frequently has benign evaluation despite the high rate of local recurrence. About $80 \%$ of $\mathrm{BCC}$ s are located in the head or neck. Several lines of evidence suggest that the worldwide incidence of $\mathrm{BCC}$ is increasing ${ }^{42}$. Metastatic $\mathrm{BCC}$ is extremely rare, with the incidence rates up to $0.5 \%$. It is defined as a primary cutaneous $\mathrm{BCC}$ that spreads to distant sites as histologically similar metastatic deposits of $\mathrm{BCC}^{43}$.

Patients with oral and maxillofacial tumors have a high risk of local recurrence, but the risk of distant recurrence is 1 low $^{4}$. Recurrence was found in only 31 (3.1\%) of all included patients, with no data on the region cancer recurrence. For instance, Montero and Patel $^{4}$ report that the possibility of a second head and neck cancer is only $4 \%-7 \%$ per year because comprehensive clinical examinations and already a high suspicion in such cancer patients are the main reasons for early diagnosis and early detection.

The main strength of this study was its design. Although it was retrospective analysis of data, it was based on the method of population-based data, which were collected in a precise and rigorous manner from medical files in order to know all the characteristics of the cancer patients included in final analysis. Thus, despite some absent data from medical records, missing values were minor. The inclusion of patients from the cancer archive allowed us to overcome recruitment bias and gave us information on the totality of cancer cases in the given geographic area of Kosovo. The main limit of our study was the limited study area, since data were only obtained from one archive instead of multiple centres, and consequently a relatively small number of patients were included in the 3-year analysis. However, this study required an extended, standardized, dedicated registration, since in Kosovo we do not run cancer registries for collection and management of data from patients with oral, neck or head cancers. So, this was the first study of this kind conducted in Kosovo. Another limitation was design of the study, which did not assess all patient data and information. Time elapsed between diagnosis and treatment (time-totreat) was investigated and showed considerable delay. It was generally long (median approximately 9 months, mean 22 months), however, we often could not identify the reason for this. Despite recommendations for early detection, cancers are still diagnosed rather late in Kosovo.

\section{Conclusions}

Oral cancers significantly contribute to patient mortality and morbidity, especially when detected late in the course of disease. This study highlighted data on gender distribution of cancer and provided information on anatomic locations where oral cancers were frequently detected. Considering prevalence data, clinicians should pay attention to the cheek region, mucosa and lip for early detection of cancers, since these regions were most common in our study. This study also showed differences between age groups, where elderly had a much higher probability of oral cancers compared to younger patients.

\section{References}

1. Warnakulasuriya S. Causes of oral cancer - an appraisal of controversies. Br Dent J. 2009;207(10):471-5. doi: 10.1038/sj.bdj. 2009.1009

2. Dhanuthai K, Rojanawatsirivej S, Thosaporn W, et al. Oral cancer: a multicenter study. Med Oral Patol Oral Cir Bucal. 2018;23(1):e23-e29. doi: 10.4317/medoral.21999

3. Tandon P, Dadhich A, Saluja H, Bawane S, Sachdeva S. The prevalence of squamous cell carcinoma in different sites of oral cavity at our Rural Health Care Centre in Loni, Maharashtra 
- a retrospective 10-year study. Contemp Oncol (Pozn). 2017; 21(2):178-83. doi: 10.5114/wo.2017.68628

4. Montero PH, Patel SG. Cancer of the oral cavity. Surg Oncol Clin N Am.2015;24(3):491-508. doi: 10.1016/j.soc.2015.03.006

5. Dumache R. Early diagnosis of oral squamous cell carcinoma by salivary microRNAs. Clin Lab. 2017;63(11):1771-6. doi: 10.7754/Clin.Lab.2017.170607

6. Peterson PE. Oral cancer prevention and control. The approach of the World Health Organisation. Oral Oncol. 2009;45 (4-5):454-60. doi: 10.1016/j.oraloncology.2008.05.023

7. Ferlay J, Steliarova-Foucher E, Lortet-Tieulent J, et al. Cancer incidence and mortality patterns in Europe: estimates for 40 countries in 2012. Eur J Cancer. 2013;49(6):1374-403. doi: 10.1016/j.ejca.2012.12.027

8. Ligier K, Belot A, Launoy G, et al. Descriptive epidemiology of upper aerodigestive tract cancers in France: incidence over 1980-2005 and projection to 2010. Oral Oncol. 2011;47(4): 302-7. doi: 10.1016/j.oraloncology.2011.02.013

9. Ligier K, Plouvier S, Danzon A, et al. Elements of completeness and results of the first year of registration of the "Registre général des cancers de Lille et de sa région”. Rev Epidemiol Sante Publique. 2012;60(2):131-9. doi: 10.1016/j.respe.2011.10.006

10. Righini CA, Karkas A, Morel N, et al. Risk factors for cancers of the oral cavity, pharynx (cavity excluded) and larynx. Presse Med. 2008;37(9):1229-40. doi: 10.1016/j.lpm.2008.03.010

11. Ghantous Y, Yaffi V, Abu-Elnaaj I. Oral cavity cancer: epidemiology and early diagnosis. Refuat Hapeh Vehashinayim (1993). 2015;32(3):55-63.

12. Mehanna H, Paleri V, West CM, Nutting C. Head and neck cancer - Part 1: Epidemiology, presentation, and preservation. Clin Otolaryngol. 2011;36(1):65-8. doi: 10.1111/j.1749-4486.2010.02231.x

13. Perry BJ, Zammit AP, Lewandowski AW, et al. Sites of origin of oral cavity cancer in nonsmokers $v s$ smokers: possible evidence of dental trauma carcinogenesis and its importance compared with human papillomavirus. JAMA Otolaryngol Head Neck Surg. 2015;141(1):5-11. doi: 10.1001/jamaoto.2014.2620

14. Pelucchi C, Gallus S, Garavello W, Bosetti C, La Vecchia C. Cancer risk associated with alcohol and tobacco use: focus on upper aero-digestive tract and liver. Alcohol Res Health. 2006;29(3): 193-8.

15. Marttila E, Uittamo J, Rusanen P, Lindqvist C, Salaspuro M, Rautemaa R. Acetaldehyde production and microbial colonization in oral squamous cell carcinoma and oral lichenoid disease. Oral Surg Oral Med Oral Pathol Oral Radiol. 2013;116(1):61-8. doi: 10.1016/j.oooo.2013.02.009

16. Feller L, Chandran R, Khammissa RA, Meyerov R, Lemmer J. Alcohol and oral squamous cell carcinoma. SADJ. 2013;68(4): 176-80.

17. Anis R, Gaballah K. Oral cancer in the UAE: a multicenter, retrospective study. Libyan J Med. 2013;8(1):21782. doi: 10.3402/ljm.v8i0.21782
18. Dhanuthai K, Rojanawatsirivej S, Subarnbhesaj A, Thosaporn W, Kintarak S. A multicenter study of oral malignant tumors from Thailand. J Oral Maxillofac Pathol. 2016;20(3):462-6. doi: 10.4103/0973-029X.190949

19. Sargeran K, Murtomaa H, Safavi SM, Vehkalahti M, Teronen O. Malignant oral tumors in Iran: ten-year analysis on patient and tumor characteristics of 1042 patients in Tehran. J Craniofac Surg. 2006;17(6):1230-3. doi: 10.1097/01.scs.000024 6728.23483.ce

20. Khan AR, Anwar N, Manan AH, Narayan KA. Case series analysis of oral cancer and their risk factors. Malaysia Dent J. 2008;29: 46-50.

21. Rawashdeh MA, Matalka I. Malignant oral tumors in Jordanians, 1991-2001. A descriptive epidemiological study. Int J Oral Maxillofac Surg. 2004;33(2):183-8. doi: 10.1054/ijom.2003.0494

22. Ariyoshi Y, Shimahara M, Omura K, et al. Epidemiological study of malignant tumors in the oral and maxillofacial region: survey of member institutions of the Japanese Society of Oral and Maxillofacial Surgeons, 2002. Int J Clin Oncol. 2008;13(3):220-8. doi: 10.1007/s10147-007-0756-9

23. Ajayi OF, Adeyemo WL, Ladeinde AL, et al. Primary malignant neoplasms of orofacial origin: a retrospective review of 256 cases in a Nigerian tertiary hospital. Int J Oral Maxillofac Surg. 2007;36(5):403-8. doi: 10.1016/j.ijom.2007.01.007

24. Singh MP, Kumar V, Agarwal A, Kumar R, Bhatt MLB, Misra S. Clinico-epidemiological study of oral squamous cell carcinoma: a tertiary care centre study in North India. J Oral Biol Craniofac Res. 2016;6(1):31-4. doi: 10.1016/j.jobcr.2015. 11.002

25. Shenoi R, Devrukhkar V, Chaudhuri, Sharma B K, Sapre S B, Chikhale A. Demographic and clinical profile of oral squamous cell carcinoma patients: a retrospective study. Indian J Cancer. 2012;49(1):21-6. doi: 10.4103/0019-509X.98910

26. BenNasir E, El Mistiri M, McGowan R, Katz RV. Oral cancer in Libya and development of regional oral cancer registries: a review. Saudi Dent J. 2015;27(4):171-9. doi: 10.1016/j. sdentj.2015.05.002

27. Subhashraj K, Orafi M, Nair KV, El-Gehani R, Elarbi M. Primary malignant tumors of orofacial region at Benghazi, Libya: a 17 years review. Cancer Epidemiol. 2009;33(5):332-6. doi: 10.1016/j.canep.2009.10.009

28. Brandizzi D, Gandolfo M, Velazco ML, Cabrini RL, Lanfranchi HE. Clinical features and evolution of oral cancer: a study of 274 cases in Buenos Aires, Argentina. Med Oral Patol Oral Cir Bucal. 2008;13(9):E544-8.

29. Bhattacharjee A, Chakraborty A, Purkaystha P. Prevalence of head and neck cancers in the north east - an institutional study. Indian J Otolaryngol Head Neck Surg. 2006;58(1):15-9. doi: 10.1007/BF02907731

30. Maleki D, Ghojazadeh M, Mahmoudi SS, et al. Epidemiology of oral cancer in Iran: a systematic review. Asian Pac J Cancer Prev. 2015;16(13):5427-32. DOI: 10.7314/apjcp.2015.16.13.5427 
31. Johnson NW. Orofacial neoplasms: global epidemiology, risk factors and recommendations for research. Int Dent J. 1991; 41(6):365-75.

32. Chidzonga MM. Oral malignant neoplasia: a survey of 428 cases in two Zimbabwean hospitals. Oral Oncol. 2006;42 (2):177-83. DOI: 10.1016/j.oraloncology.2005.07.003

33. Howell RE, Wright BA, Dewar R. Trends in the incidence of oral cancer in Nova Scotia from 1983 to 1997. Oral Surg Oral Med Oral Pathol Oral Radiol Endod. 2003;95(2):205-12. DOI: $10.1067 /$ moe.2003.49

34. Ali J, Sabiha B, Jan HU, Haider SA, Khan AA, Ali SS. Genetic etiology of oral cancer. Oral Oncol. 2017;70:23-8. DOI: 10.1016/j.oraloncology.2017.05.004

35. Hussein AA, Helder MN, de Visscher JG, et al. Global incidence of oral and oropharynx cancer in patients younger than 45 years versus older patients: a systematic review. Eur J Cancer. 2017;82:115-27. DOI: 10.1016/j.ejca.2017.05.026

36. Di Lernia V, Ricci C, Zalaudek I, Argenziano G. Metastasizing basal cell carcinoma. Cutis. 2013;92(5):244-6.

37. Lear JT, Dziewulski P, Ross GL, et al. Challenges and new horizons in the management of advanced basal cell carcinoma: a
UK perspective. Br J Cancer. 2014;111(8):1476-81. DOI: 10.1038/bjc.2014.270

38. Berking C, Hauschild A, Kölbl O, et al. Basal cell carcinoma treatments for the commonest skin cancer. Dtsch Arztebl Int. 2014;111(22):389-95. DOI: 10.3238/arztebl.2014.0389

39. Lomas A, Leonardi-Bee J, Bath-Hextall F. A systematic review of worldwide incidence of nonmelanoma skin cancer. Br J Dermatol. 2012;166(5):1069-80. DOI: 10.1111/j.1365-2133. 2012.10830.x

40. Samarasinghe V, Madan V. Nonmelanoma skin cancer. J Cutan Aesthet Surg. 2012;5(1):3-10. DOI: 10.4103/0974-2077.94323

41. Weiss GJ, Korm RL. Metastatic basal cell carcinoma in the era of hedgehog signalling pathway inhibitors. Cancer. 2012;118 (21):5310-9. DOI: $10.1002 /$ cncr. 27532

42. Mohan SV, Chang AL. Advanced basal cell carcinoma and therapeutic innovations. Curr Dermatol Rep. 2014;3:40-5. doi: 10.1007/s13671-014-0069-y

43. Moser S, Borm J, Mihic-Probost D, Jacobsen C, Kruse Gujer AL. Metastatic basal cell carcinoma: report of a case and review of the literature. Oral Maxillofac Surg. 2014;117(2):e79-82. DOI: $10.1016 /$ j.oooo.2012.04.030

Sažetak

\section{ANALIZA TROGODIŠNJE UČESTALOSTI TUMORA USNE ŠUPLJINE, VRATA I GLAVE - RETROSPEKTIVNO ISTRAŽIVANJE U JEDNOM CENTRU}

\section{S. Rusinovci, X. Aliu, T. Jukić, D. Śtubljar i N. Haliti}

Cilj ovoga istraživanja bio je analizirati učestalost tumora usne šupljine, vrata i glave u našoj klinici tijekom trogodišnjeg razdoblja. Retrospektivnom analizom obuhvaćeni su arhivski podaci za bolesnike s karcinomom liječene na našoj klinici od 2015. do 2017. godine. Za konačnu analizu odabrano je ukupno 1005 bolesnika s dokazanim karcinomom. Karcinomi su otkriveni ultrazvukom, rendgenskim snimanjem, biopsijom i kliničkom dijagnostikom. Srednja dob bolesnika bila je $58,4 \pm 19,3$ godine. Većina slučajeva $(n=264 ; 26,3 \%)$ otkrivena je u sedmom desetljeću života. Najčešći tipovi karcinoma bili su bazocelularni karcinom utvrđen u $374(37,2 \%)$ i planocelularni karcinom u $228(22,7 \%)$ slučajeva. Omjer muških i ženskih bolesnika bio je 1,7:1. Među spolovima nije bilo statistički značajne razlike u dobi. Ponovna pojava tumora zabilježena je u 31 bolesnika. Izlaganje suncu bio je najčešći čimbenik rizika u objema skupinama. Najčešća mjesta nastanka tumora bili su donja usnica, obrazi i frontalna regija kod muškaraca te područje obraza i nos kod žena $(p<0,001)$. Vjerojatnost razvoja karcinoma bila je veća kod muškaraca. Studija je pokazala razlike među dobnim skupinama, tj. vjerojatnost razvoja karcinoma bila je znatno veća kod starijih bolesnika u usporedbi s mlađim bolesnicima.

Ključne riječi: Trogodišnji podaci; Učestalost; Karcinomi usne šupljine; Čimbenici rizika; Retrospektivna analiza 